\title{
Etički izazovi reproduktivne medicine i Zakona o medicinski pomognutoj oplodnji u kontekstu istospolnih zajednica
}

Mislav Kutleša*

mkmoraltheol32@hotmail.com

Mladen Škvorc ${ }^{* * *}$

mlaskvor@gmail.com
UDK: 612.63:616]:17

316.361 .15

Pregledni članak / Review

Primljeno: 5. lipnja 2016.

Prihvaćeno: 20. listopada 2016.

Čitavo 20. stoljeće označio je nagao i ubrzan razvoj znanosti, među kojima na poseban način izdvajamo medicinu, biomedicinu i biotehniku, koje nikoga nisu ostavile ravnodušnim, što je vidljivo u raspravama o odnosu znanosti $i$ etike. Iako su se navedene znanosti brzo razvijale, ostvarujući zadivljujuće uspjehe na području ljudskog zdravlja $i$ života, sve se više razvijala svijest o potrebi poštivanja etičkih principa. Pri tomu su se etički principi prvenstveno odnosili na položaj, vrijednost $i$ dostojanstvo čovjeka u horizontima znanstvenoga dosega $i$ istraživanja. Suvremeni prijepor je stvorila reproduktivna medicina, odnosno medicinski pomognuta oplodnja. Iako je u početku umjetna oplodnja bila provođena unutar bračnih i izvanbračnih neplodnih parova, u novije se doba posebna etička poteškoća pojavila u kontekstu istospolnih zajednica koje de facto imaju jednaka prava kao i (izvan)bračne zajednice muškarca $i$ žene. Pri čemu na poseban način izdvajamo pravo na potomstvo ostvarivo medicinski pomognutom oplodnjom.

Ključne riječi: medicinski pomognuta oplodnja, neplodnost, Zakon o MPO, pravo na dijete, istospolna zajednica, odgovorna prokreacija.

\footnotetext{
* Dr. sc. Mislav Kutleša, viši asistent, Katolički bogoslovni fakultet Sveučilišta u Zagrebu; Vlaška 38, pp 432, HR-10001 Zagreb.

**Mr. Mladen Škvorc, vicekancelar Nadbiskupskoga duhovnog stola Zagrebačke nadbiskupije; Kaptol 31, pp 553, HR-10001 Zagreb.
} 


\section{Uvod}

Povijest znanstvenoga napretka svjedoči nam kako se ukorak s vremenom povećavala i etička svijest o vrijednosti ljudskoga života te nepovredivosti i nedodirljivosti njegova dostojanstva, što se vidi iz proglašenja povelje o ljudskim pravima, a što je pak utjecalo na medicinske, biomedicinske i biotehnološke znanosti. Pred etičkim »zaprekama« u znanstvenom istraživanju počelo se tvrditi da je njihov temeljni etički zahtjev i odgovornost u nastojanju da se čovjeku osigura što kvalitetniji život. Tako se razvoj medicinskih i biomedicinskih znanosti i tehnike očitovao kao svojevrstan odgovor na čovjekovu biološku/ tjelesnu ograničenost ili nesposobnost uzrokovanu raznim psiho-fizičkim bolestima ili manama. Vodeći se idejom služenja, napredak navedenih znanosti je imao pozitivno usmjerenje. Međutim, te su se znanstvene discipline s vremenom gotovo »mesijanski« nametnule čovječanstvu smatrajući svojim ciljem izbaviti ga iz »zatvorenog kruga« psiho-fizičkih ograničenja, razočarenja, očaja i depresivnog stanja uzrokovanoga tjelesnom bolešću, pa čak i po cijenu zanemarivanja rečenog etičkog principa.

U napetom ozračju odnosa između etike i znanosti, a koji nerijetko uključuju pitanja vezana za početak i svršetak ljudskog života, znanost se morala suočiti s temeljima općeg dobra - prirodnim i božanskim moralnim zakonima, a potom i s ljudskim pozitivnim zakonom. Štoviše, u kontekstu znanstvenotehnološkog napretka nastala je i vizija novog manifesta laičke bioetike ${ }^{1}$ koja je dala zanimljiv odgovor na mnoga moralna pitanja u odnosu na granice ljudske slobode i odgovornosti u svijetu znanstvenog istraživanja i izbora pojedinaca na području ljudskog zdravlja, života i smrti. Moralni su se principi počeli mijenjati, a etičke granice pomicati prema mogućnostima koje suvremena znanost može pružiti. Napredak medicinskih i biomedicinskih znanosti i tehnike, ali i drugih znanosti, omogućio je suvremenom čovjeku uvid u »novi svijet« morala i moralnosti čije su granice u mogućnostima suvremene znanosti, a ne $\mathrm{u}$ vječnim zakonima. Kao da moralne smjernice proizišle iz vječnog zakona ubrzano blijede pred novim izazovima i mogućnostima koje nam pružaju znanosti. Ovdje ćemo svoju misao usmjeriti isključivo $k$ umjetno izvedenoj ljudskoj prokreaciji, tj. umjetnoj oplodnji.

Neosporno je da mnogi parovi i prije ulaska u bračnu ili izvanbračnu zajednicu aktivno i odgovorno razmišljaju o svojemu poslanju i odgovornosti, vodeći računa o prokreativnom karakteru i smislu bračne ljubavi i sjedinjenja. Istovremeno, nemali broj parova pati od sve raširenije bolesti koja uzrokuje istinsku i duboku tjelesnu, duhovnu i psihološku patnju - neplodnosti. Ona je izazov znanosti: kako da se onima koji žele potomstvo to i omogući. Štoviše, znanost je na taj način težila realizaciji svoje humanosti služenjem čovjeku, obiteljskoj

${ }^{1}$ Usp. Maurizio MORI i dr., Nuovo manifesto di bioetica laica, (28.02.2008) www.paleopatologia.it/articoli/aticolo.php?recordID=31 (28.05.2016). 
zajednici i društvu - a što se kasnije pokazalo i kao svojevrstan privid s obzirom na sve ubrzaniji razvoj genetskog inženjeringa i izravnih zahvata u novi ljudski život. ${ }^{2}$ Zahvaljujući napretku znanosti, čime je ostvaren velik uspjeh u reproduktivnoj medicini, sve je više problematika potomstva postajala etički problem jer se naglasak premještao sa želje na potomstvo na pravo na potomstvo.

»Očajnička želja za potomstvom, savjesna stagnacija, moralna ignorancija, no i sveopća neupućenost vjernika u stvarno pozadinsko stanje, zaslijepljeni su apsolutnim povjerenjem $u$ te, sve prestižnije medicinske tehnike prokreacije. Od jednostavnijih se metoda sve postupnije prelazi na one agresivnije i kompleksnije metode asistirane oplodnje, koje za sobom povlače sve oštriji moralni sud, bilo zbog neprihvatljivih rizika, propusta i potencijalnih genetskih manipulacija, ali i zakonodavstvenim nedefiniranostima ili neprihvatljivim odobrenjima. « ${ }^{3}$

Očajnička želja za ostvarivanjem potomstva zanemarila je prvotni zadatak medicinske prakse: liječiti, a ne zaobilaziti problematiku/bolest neplodnosti, osobito danas kada pravo i sloboda sve više stavljaju pod upitnik sam pojam braka kao isključive zajednice muškarca i žene.

Prvo je poglavlje ovoga rada usmjereno na traženje medicinskog i pravnog razloga za MPO, dok je u drugom poglavlju pogled usmjeren na etičku i antropološku problematiku unutar istospolnih zajednica i njihove želje za potomstvom.

\section{Medicinsko i pravno tumačenje neplodnosti radi ostvarivanja prava na MPO}

\subsection{Medicinski kriteriji utvrdivanja neplodnosti}

MPO je najnovija metoda ili revolucionarno otkriće medicinske i bioteh-

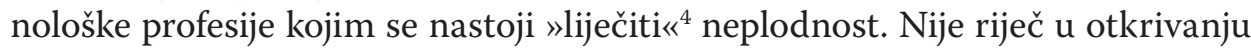
novih tehničkih sredstava i metoda služenja ljudskom životu, već ono nužno potiče i razvoj moralne svijesti o humanizaciji medicinske znanosti koja teži dati kvalitetan odgovor svakom čovjeku u kontekstu života i zdravlja.

\footnotetext{
${ }^{2}$ Valentina VUKOJE, Znanost bez granica. Stvaranje djeteta s tri roditelja i bez teških bolesti (24.12.2015), http://zg-magazin.com.hr/znanost-bez-granica-stvaranje-djeteta-s-tri-roditeljai-bez-teskih-bolesti/ (28.05.2016).

${ }^{3}$ Suzana VULETIĆ, Problem neplodnosti i moralni izazovi biomedicinskih zahvata u ljudsko rađanje, Diacovensia, 18 (2010) 3, 587-616, 589.

${ }^{4}$ Riječ liječiti namjerno je stavljena u navodnike zato što se u kontekstu MPO ne može govoriti o pravoj terapiji, odnosno o metodologiji liječenja neplodnosti. U prilog tome izdvajamo: Tonči MATULIĆ, Kritička evaluacija vrijednosne supstancije pravne regulacije tzv. medicinski potpomognute oplodnje, Zbornik Pravnog fakulteta u Zagrebu, 56 (2006) 5, 1372-1377.
} 
U posljednjih je 40-ak godina medicina, zajedno s biotehnološkim znanostima, prihvatila bitno drukčiji smjer i bitno drukčiju etičku dimenziju, što dovodi u pitanje izvorni smisao medicinske prakse, a koji se prvenstveno odnosi na pitanja života i smrti, odnosno pobačaja ili eutanazije, potom kloniranja, genetskog inženjeringa, ali i na pitanja o najdubljoj želji bračnih parova - a to je prokreacija/potomstvo - koju nisu u mogućnosti realizirati uslijed vlastite neplodnosti. Novim dostignućima i mogućnostima se počelo prelaziti s ideje služenja i obrane svakog ljudskog života i njegova dostojanstva od začeća, na ideološki i eugenički pristup služenju ljudskim narcističkim željama koje su iznjedrile pojavu novih temeljnih »ljudskih prava«. Jedno od tih prava postalo je i pravo na potomstvo. Ovo posljednje nas se na poseban način tiče u ovom radu jer se, nakon utvrđene neplodnosti, osoba/par odlučuje na umjetnu oplodnju. Već je time istaknut jasan okvir i razlozi iz kojih proizlazi zahtjev za MPO, odnosno da je MPO prvenstveno liječnička metoda pružanja pomoći i ostvarivanja potomstva kod neplodnih parova.

Neplodnost, naime, u kontekstu ljudske seksualnosti i želje za potomstvom, nije samo izazov medicinskoj praksi već ponajprije stvarna osobna prepreka nemalom broju bračnih parova da ostvare svoju dvostruku ulogu:

a) horizontalnu ulogu, odnosno odgovornost prema sebi i društvu obogaćujući svoju bračnu zajednicu i društvo novim članovima te

b) vertikalnu ulogu, odnosno odgovornost prema Bogu, prihvaćajući ulogu suradnika Božjih u djelu stvaranja poštujući zapovijed: »Plodite se i množite i napunite zemlju (Post 1,28 ).

U kontekstu kršćanskog braka ne treba zanemariti niti obećanje izrečeno tijekom sklapanja sakramenta ženidbe, tj. da su bračni partneri »spremni s ljubavlju od Boga primiti djecu i odgajati ih po zakonu Krista i njegove Crkve. $\aleph^{5}$ Što, usput budi rečeno, naglašava status djeteta kao Božjeg dara, tj. da se dijete vrednuje i prihvaća kao dar i plod uzajamnog darivanja u ljubavi bračnih partnera, a nije proizvod suradnje roditelja i znanstvenika. Neplodnost dakle ostaje stvarna prepreka, patnja i izazov na osobnoj-društvenoj-religijskoj razini za mnoge bračne parove i za medicinu koja je pozvana i dužna po svojoj naravi služiti i pomagati čovjeku u pitanjima zdravlja i života.

U tom se smislu neplodnost već i prije tumačila isključivo kao bolest ljudskog reproduktivnog sustava. U medicinskim je okvirima neplodnost utvrđena prema sasvim jasnim fizičkim činjenicama:

»Bračna neplodnost je pojava kada žena ne može zanijeti tijekom bar dvije godine urednoga spolnoga života, a bez kontracepcije. Neplodnost je primarna ako žena nije nikada zanijela, a sekundarna ako ne može zanijeti nakon prethodnih trudnoća. Procjenjuje se da je oko $15 \%$ brakova neplodno. U oko $30 \%$ neplodnih brakova uzrok je u muškarca. Oplodna sposobnost muškarca ovisi prije svega o broju i pokretnosti spermija u jednom ejakulatu, pa i o ostalim

\footnotetext{
${ }^{5}$ Usp. Red slavljenja ženidbe, Zagreb, Kršćanska sadašnjost, 1997, br. 60.
} 
kvalitetama sperme. Manje vrijedna sperma može biti posljedica poremećene spermiogeneze ili zaprjeke $u$ izlučivanja sjemena. I protutijela protiv muževljevih spermija u cervikalnoj sluzi žene mogu razoriti spermije i uzrokovati neplodnost. Izostanak ovulacije kao uzrok neplodnosti pojavljuje se u oko $25 \%$ sterilnih brakova. Okluzija jajovoda također je čest uzrok neplodnosti i pojavljuje se u oko 25 \% sterilnih brakova. Oštećenja jajovoda najčešće su posljedica upale i endometrioze. ${ }^{6}$

Svjetska zdravstvena organizacija (dalje: SZO) ima za neplodnost jednako jasan i nedvosmislen stav, smatrajući da je to bolest reproduktivnog sustava utvrđen nemogućnošću trudnoće nakon 12 ili više mjeseci regularne i nezaštićene seksualne interakcije, ${ }^{7}$ a koji zahvaća otprilike 15 \% parova reprodukcijske dobi. ${ }^{8}$ Jasno su utvrđeni i okviri po kojima se utvrđuje neplodnost, a koji ovise o mnogostrukim faktorima osobe, odnosno bračnoga para. Neplodnost je najčešće »rezultat anatomskih, fizioloških ili endokrinoloških nepravilnosti«. ${ }^{9}$ Dakle,

»za postizanje začeća muškarac mora biti sposoban unijeti odgovarajući broj funkcionalno normalan broj spermija u gornji dio rodnice partnerice u odgovarajućem periovulacijskom razdoblju. Znači da muškarac mora imati primjerenu spermatogenezu, što uključuje uspješnu maturaciju sperme u epidimisu, uredan prijenos sperme, odgovarajuću funkciju akcesornih žlijezda i pravilnu erektilnu i ejakulacijsku funkciju. Žena mora imati uredan ovulacijski ciklus, prikladnu cervikalnu sluz koja omogućava preživljavanje spermija, odgovarajući endometrij u maternici i dobro prohodne jajovode. Poremećaji navedenih funkcija dovode do neplodnosti. ${ }^{10}$

Ostali čimbenici koji direktno utječu na (ne)plodnost bračnih parova su životna dob roditelja (sve je veći broj onih koji odgađaju prvu trudnoću čak i nakon 35 godina života) i psihološki razlozi (stres, depresija, anksioznost...). ${ }^{11}$ Proizlazi da je neplodnost definirana kao bolest osobe, odnosno da je dijagnostičkim sredstvima moguće otkriti patologiju koja može biti direktan uzrok neplodnosti. ${ }^{12}$ Pri tomu se osobiti naglasak stavlja na činjenicu da je uvijek riječ o pravoj patologiji, odnosno bolesti jednog ili obaju bračnih partnera. Anali-

\footnotetext{
${ }^{6}$ Josip DJELMIŠ, Etika u perinatalnoj i reproduktivnoj (prokreacijskoj) medicini, u: Niko ZURAK (ur.), Medicinska etika, Zagreb, Merkur A. B. D., 2007, 95-104, 98.

7 Usp. WORLD HEALTH ORGANISATION - HUMAN REPRODUCTION PROGRAMME, Sexual and reproductive health, www.who.int/reproductivehealth/topics/infertility/definitions/en/ (25.05.2016).

${ }^{8}$ Renato BAUMAN, Obrada i terapija neplodnosti, Medicina fluminensis, 45 (2009) 4, 300-312, 301.

${ }^{9}$ Isto.

${ }^{10}$ Isto.

${ }^{11}$ Usp. Miljenko ANIČIĆ, Bračna neplodnost i njezine mogućnosti, Bogoslovska smotra, 77 (2007) 1, 181-216, 182; opširnije o psihološkim utjecajima na neplodnost vidi: Tea FRIŠČIĆ, Zorana KUŠEVIĆ, Najčešći psihološki problemi kod parova u procesu potpomognute oplodnje, Socijalna psihijatrija, 41 (2013) 2, 99-108.

${ }^{12}$ Usp. Bauman, Obrada i terapija neplodnosti..., 303.
} 
zom navedenoga stava SZO-a i medicinske prakse uopće, dolazimo do jasno istaknutih osnovnih etičkih i antropoloških zahtjeva i okvira u kojima se može utvrđivati neplodnost. Oni nužno uključuju dva temeljna uvjeta:

1) antropološku komplementarnost, tj. zahtijevaju spolnu različnost (muško-žensko) i

2) redovitu nezaštićenu seksualnu aktivnost unutar tih antropoloških zahtjeva.

Ako se nakon 12 i više mjeseci utvrdi da nezaštićena seksualna aktivnost bračnih partnera nije urodila plodom, partneri mogu uz pomoć liječnika utvrditi razloge svoje neplodnosti, tj. je li neplodnost biološke ili psihološke naravi, pri čemu bi se samo biološka neplodnost mogla smatrati pravom neplodnošću. Dakle, neplodnost se definira

»kao nedostatak željene trudnoće uz redovite, nezaštićene spolne odnose u razdoblju od najmanje godinu dana. Neplodnost ima svoje varijacije, tako razlikujemo: sterilnost = nemogućnost začeća; primarna sterilnost $=$ odsutnost trudnoće; sekundarna sterilnost $=$ nemogućnost začeća nakon prethodnih trudnoća; neplodnost = nemogućnost iznijeti trudnoću do kraja. $\aleph^{13}$

U sva četiri navedena pokušaja definiranja neplodnosti/sterilnosti jasno je istaknuto da će se neplodnost utvrditi samo u slučajevima nezaštićenog spolnog sjedinjenja između muškarca i žene. Prema tome, utvrđivanje neplodnosti kao nemogućnosti prokreacije je jasno usmjerena na poštivanje temeljnog antropološkog plana: različitosti u spolnosti. Ovime se dakako ne želi izostaviti mogućnost provjere plodnosti na inicijativu osobe prije ulaska u brak ili izvanbračnu zajednicu, ali se ističe najrašireniji način: muško-žensko u nezaštićenom sjedinjenju, bračnom činu. U tim okolnostima medicinska praksa ukazuje na medicinske razloge kojima utvrđuje dijagnozu i eventualno patološko stanje jednoga ili obaju bračnih partnera. Jedino se u tim okvirima može utvrditi da je riječ o pravoj neplodnosti.

Ne treba zanemariti ni činjenicu da danas sve veći broj bračnih parova odgađa svoju prvu trudnoću, neovisno o njihovim razlozima. Stoga se pri utvrđivanju neplodnosti treba uzeti u obzir i utjecaj životne dobi na plodnost žene.

Ne gledajući trenutno ovaj posljednji razlog neplodnosti (dob), ona ostaje definirana kao bolest koju treba nastojati izliječiti i izlječenjem omogućiti bračnim parovima da nezaštićenim seksualnim interakcijama ostvare svoju legitimnu naravnu ljudsku i kršćansku želju za potomstvom. U tom je duhu medicina, osobito s etičke strane, promatrala i vrednovala MPO kao način pomaganja bračnim parovima u ostvarivanju potomstva. Time se, međutim, ne želi zanemariti ili umanjiti neetičnost MPO u medicinskom smislu, odnosno da takvi zahvati zamjenjuju bračni čin, već istaknuti okviri i okolnosti u kojima bi se trebala obavljati MPO, barem iz perspektive medicinske struke.

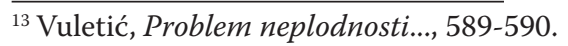




\subsection{Pravni kriteriji utvrđivanja neplodnosti i uređivanja prava na $M P O$}

Nakon jasno opisanih medicinskih kriterija, etičkih i antropoloških uvjeta te metodologije utvrđivanja neplodnosti osobe ili bračnog para, koja je izričito psiho-fizičkog karaktera, nužno je da uzmemo u obzir i pravno utvrđivanje prava na MPO nakon utvrđene neplodnosti i istinske želje za potomstvom. $U$ tu je svrhu Republika Hrvatska donijela Zakon o medicinski pomognutoj oplodnjiit (dalje: Zakon o MPO) koji je stupio na snagu 4. kolovoza 2012. godine, a kojim se utvrđuje stanje neplodnosti i regulira pravo na MPO. Taj je zakon unio etičku i antropološku zbrku i proturječnost u medicinsko utvrđivanje neplodnosti. Njegovim se pregledom lako može utvrditi da je odnos između medicinskog i pravnog tumačenja neplodnosti i njenog utvrđivanja kod osobe ili para u nekim važnim točkama suprotstavljen i nedorečen, bez jasnih antropoloških i etičkih okvira, pa se iz toga mogu izvoditi i neželjeni zaključci. U njemu je pravno prošireno tumačenje neplodnosti i broj uključenih osoba, odnosno mogućih involviranih subjekata. Dotadašnja medicinska metodologija utvrđivanja neplodnosti i ostvarivanje prava na MPO, koja je bila isključivo psiho-fizičkog karaktera, gotovo je u potpunosti zaobiđena i zanemarena, a po ovom Zakonu o MPO, prava neplodnost više nije jedini razlog za korištenje prava na MPO.

U samom početku Zakon o MPO, kao i medicinska praksa, postavlja prije svega uvjet pod kojim se osoba ili par može pozvati na pravo na MPO - neplodnost:

»Medicinski pomognuta oplodnja jest postupak koji se provodi tek kada je dotadašnje liječenje neplodnosti bezuspješno ili bezizgledno, te radi izbjegavanja prijenosa teške nasljedne bolesti na dijete kod prirodnog začeća« (čl. 4, st. 1).

Iako se stječe dojam da zakon slijedi postavke medicinske struke, unutar istoga članka nastaje suprotstavljenost medicine i prava, jer principi nisu u svemu jednaki. Neprihvatljiva su i odobrenja njime propisana. Zakon o MPO kao da nikoga i ni u čemu ne želi »zakinuti«, kao da izbjegava »diskriminaciju« osoba koje ne žive u bračnoj ili izvanbračnoj zajednici, odnosno koje žive samačkim životom. Time zakon sugerira da dijete nije dar nego pravo neke ljudske osobe.

Budući da Zakon o MPO govori isključivo o pravu žena na MPO, otvara se novo etičko pitanje koje otkriva novu diskriminaciju: A što je s muškom populacijom? Tako se Zakon o MPO više ne bavi isključivo problemom neplodnosti, odnosno ne određuje pravo na MPO polazeći od neplodnosti, već ponajprije od subjekata, osoba koje traže to pravo. Zakon o MPO je iznevjerio medicinsku metodologiju utvrđivanja neplodnosti te znatno proširio "popis« subjekata koji

\footnotetext{
${ }^{14}$ Narodne novine, br. 86, 27. srpnja 2012, http://narodne-novine.nn.hr/clanci/sluzbeni/2012 07_86_1962.html (25.05.2016).
} 
mogu zatražiti pravo na MPO, a ti subjekti - osim heteroseksualnih bračnih i izvanbračnih parova - mogu biti i žene samci, a time i de facto osobe koje žive $\mathrm{u}$ istospolnoj zajednici, barem lezbijski parovi čija veza još nije ozakonjena.

Analizirajući Zakon o MPO i njegova tumačenja neplodnosti i prava na MPO utvrdimo najprije medicinsku činjenicu koja zorno pokazuje razliku između pravnog i medicinskog tumačenja prava na MPO. Medicinska praksa utvrđivanja neplodnosti zahtijeva da je riječ o heteroseksualnim osobama koje su u bračnoj ili izvanbračnoj zajednici. Naglašena je ne samo komplementarnost u spolnoj različitosti već i postojanje zajednice muškarca i žene kao jedinog zdravog ljudskog okoliša za dijete, za njegov cjelovit rast i razvoj. Drugim riječima, u kriterijima utvrđivanja neplodnosti i prava na MPO medicinska praksa vodi računa o odgovornom roditeljstvu, barem antropološki gledano.

Tim se jasno utvrđenim medicinskim kriterijima suprotstavlja Zakon o MPO, koji već u početku jasno tvrdi da je donesen zato da uređuje pravo osoba na MPO:

»Ovim se Zakonom uređuju uvjeti za ostvarivanje prava na medicinski pomognutu oplodnju te prava, obveze i odgovornosti svih sudionika postupaka medicinski pomognute oplodnje« (čl. 1, st. 1).

Postavlja se pitanje: Utvrđuju li se kriteriji polazeći od osoba ili od neplodnosti kao istinskog zdravstvenog problema? Naime, ako se polazi od osobe kao nositelja ljudskih prava, tada je nepotrebno pozivati se na neplodnost, kao u slučaju žena koje ne žive ni u kakvoj vezi, bračnoj ili izvanbračnoj, te u slučaju istospolnih parova.

Nadalje, valja istaknuti i glavne točke suprotstavljanja Zakona o MPO i medicinske prakse, ali i proturječnosti unutar Zakona o MPO. Naime, u čl. 4. Zakona o MPO utvrđuje se najprije razlog provedbe postupka MPO, naglašavajući da je prvi zadatak medicinske prakse utvrditi bolest, tj. dijagnosticirati neplodnost osobe. Prema tome, zakonom su utvrđeni kriteriji koji slijede medicinsku metodologiju utvrđivanja neplodnosti osobe ili para koji je u bračnoj vezi (ili nije), a koju utvrđuje liječnik specijalist ginekologije i opstetricije s užom specijalizacijom iz humane reprodukcije (čl. 4., st. 2.). U skladu s tim čl. 10., st. 1. navodi:

»Pravo na medicinski pomognutu oplodnju uz uvjete iz članka 4. ovoga Zakona imaju punoljetni i poslovno sposobni žena i muškarac koji su u braku, odnosno u izvanbračnoj zajednici i koji su s obzirom na životnu dob i opće zdravstveno stanje sposobni za roditeljsku skrb o djetetu. $^{15}$

Isti članak u st. 2. mijenja pogled i određuje da pravo na MPO imaju i neke druge osobe: 
»Pravo na medicinski pomognutu oplodnju ima i punoljetna, poslovno sposobna žena koja ne živi u braku, izvanbračnoj ili istospolnoj zajednici, čije je dosadašnje liječenje neplodnosti ostalo bezuspješno ili bezizgledno te koja je $\mathrm{s}$ obzirom na životnu dob i opće zdravstveno stanje sposobna za roditeljsku skrb o djetetu.«

Ovom odredbom učinjen je radikalan medicinski, društveni i moralni zaokret, i to ne samo u utvrđivanju neplodnosti već i davanjem prava na MPO. Dok je u prvom stavku navedenoga članka jasno izražena medicinska metodologija i antropološki okvir utvrđivanja neplodnosti, dotle je u drugom stavku zanemaren ovaj prvi zahtjev, tj. bračni čin između muškarca i žene. Zar se neplodnost utvrđuje vlastitom inicijativom?

Tom se odredbom Zakon o MPO, osim borbe protiv diskriminacije, opredjeljuje i za novu definiciju odgovornog roditeljstva, odnosno roditeljstva uopće, te implicitno utvrđuje pravo na dijete kao temeljno ljudsko pravo, što je u suprotnosti s istinskim dostojanstvom i dobrobiti djeteta is ustanovom braka. ${ }^{16}$

Zahvaljujući navedenom Zakonu o MPO i njegovim novim kriterijima utvrđivanja neplodnosti i ostvarivanja prava na MPO, omogućeno je korištenje umjetne oplodnje i osobama koji žive $u$ istospolnim zajednicama. Takvoj ideološkoj nastrojenosti su doprinijele i javne rasprave o slobodi i dostojanstvu istospolnih zajednica, usprkos tome što je tada više puta istaknuto da se istospolne zajednice neće moći pozivati na pravo na MPO jer ono izrijekom nije potvrđeno u zakonu.

Ako neplodnost i želju za potomstvom povežemo sa zahtjevima istospolnih zajednica, tada pitanje neplodnosti poprima posve novu dimenziju. Naime, zahvaljujući Zakonu o MPO, postaje vrlo izvjesna mogućnost da se sterilnost tumači na dva načina:

1) sterilnost u užem smislu - prema medicinskoj metodologiji i okvirima utvrđivanja neplodnosti, odnosno kada je riječ o heteroseksulanim (izvan)bračnim zajednicama koje iz zdravstvenih razloga ne mogu ostvariti svoju želju za potomstvom; i

2) sterilnost u širem smislu - kada je riječ o istospolnim zajednicama koje svoju želju za potomstvom ne mogu ostvariti iz posve jasnih antropoloških, a ne zdravstvenih razloga.

Nameće se pitanje zakonodavnoj vlasti o njezinu odnosu prema istospolnim zajednicama, a na temelju Zakona o MPO: Je li homoseksualni čin protunaravan? Je li tu riječ o pravoj patologiji, odnosno bolesti? Dakako, uzevši u obzir da istospolni par svojim seksualnim činom ni na koji način ne može biti plodan, tj. otvoren životu.

${ }^{16}$ Usp. Matulić, Kritička evaluacija..., $1390-1395$. 


\section{Medicinski pomognuta oplodnja u kontekstu istospolnih zajednica}

»Potreba za pravnim uređenjem različitih medicinskih postupaka (...) odraz je viševrsnih i pojedinačnih interesa. Vrlo se često medicinskim postupcima zadire u pravna pitanja osobnosti nekog subjekta i njegov osobni status s određenim, ponajprije obiteljskopravnim posljedicama. Pravna intervencija u medicinske zahvate stoji uvijek na raskrižju između dvojbe o slijeđenju medicinskih dostignuća (...), s jedne strane i etičkih načela, prava na samoodređenje, prava na privatnost, prava na zasnivanje obitelji, s druge strane. Uloga prava, nakon osuda, neprihvaćanja, oduševljenja i odobravanja, treba medicinsku praksu dovesti u okvire realno prihvatljivog, društveno korisnog i pravno sigurnog. ${ }^{17}$

To nije tako u slučaju našega Zakona o MPO koji dopušta da i neke osobe (žene) koje žive samački ili u istospolnoj zajednici imaju mogućnost ostvarenja prava na MPO. To se pravo ne odnosi samo na neplodnost nego je problematika znatno kompleksnija. Ona se tiče i neravnopravnog položaja muškarca koji želi biti samohrani otac, te muške istospolne zajednice. Oni su u svojoj želji za djecom onemogućeni zakonskim odredbama o zamjenskom majčinstvu (čl. 31. Zakona o MPO). Imamo i problem dostojanstva djeteta koje je začeto putem MPO.

U prethodnom smo poglavlju, naime, spomenuli da je Zakon o MPO izmanipulirao prvotni smisao MPO kao medicinske i biotehnološke metodologije pomaganja heteroseksualnim bračnim i izvanbračnim zajednicama u njihovoj želji i »pravu« za potomstvom. Ovom »manjom« zakonskom promjenom spomenuti Zakon o MPO ipak, iako neizravno, omogućuje istospolnim zajednicama neka prava koja uživaju heteroseksualni brakovi, počevši od "prava« na dijete, prava za koje se bore današnje LGBTIQ udruge, jer oni to svojim protunaravnim putem nikako ne mogu ostvariti.

U ovim slučajevima umjetna oplodnja ima ključnu ulogu. Stvara se dojam da ona postaje najveći dokaz »solidarnosti« i »pravednosti« društva u borbi protiv diskriminacije. Da bi se danas »dobilo« dijete više nije nužna seksualna prokreacija ostvarena spolnim činom muškarca i žene u tjelesnom sjedinjenju, već je to ostvarivo i aseksualnim putem - procesom umjetne oplodnje. Iako se $u$ početku kampanje, odnosno borbe za pravo na medicinski pomognutu oplodnju, društvo uvijek pozivalo na neplodne heteroseksualne parove, nepobitna je činjenica da je njezino odobravanje i ozakonjivanje omogućilo nova "prava«, a koja to uopće nisu.

Zakon o MPO omogućuje prokreaciju punoljetnim i poslovno sposobnim ženama koje ne žive u braku, ni u izvanbračnoj zajednici, čija su dosadašnja

\footnotetext{
${ }^{17}$ Dubravka HRABAR, Pravni odnosi roditelja i djece, u: Mira ALINČIĆ, Dubravka HRABAR, Dijana JAKOVAC LOZIĆ, Aleksandra KORAĆ GRAOVAC, Obiteljsko pravo, Zagreb, Narodne novine, ${ }^{3} 2007,125-307,205$.
} 
liječenja neplodnosti ostala bezuspješna ili bezizgledna te koje su, s obzirom na životnu dob i opće zdravstveno stanje, sposobne za roditeljsku skrb o djetetu (čl. 10, Zakona o MPO). Međutim, u kontekstu današnje borbe LGBTIQ udruga za pravo na djecu, zakon posredno omogućuje prokreaciju i homoseksualnim parovima, odnosno istospolnim zajednicama time što mogu imati biološko dijete jednog od partnera, uključujući i mogućnost da već sada po ovom zakonu lezbijski par ima pravo na dijete. Naime, ovakav Zakon o MPO to i izravno omogućuje, imajući u vidu ženu koja ne živi u braku i čija je »neplodnost« dokazana, ali i bezizgledna s obzirom da živi u istospolnoj vezi. Nameće se pitanje, $\mathrm{u}$ čemu je problem neplodnosti i kako utvrditi patologiju. Time iznova ulazimo u okvire u kojima bi se homoseksualnost definirala kao bolest. Prateći odredbe Zakona MPO, dovoljno je samo da osoba (ili par) dokaže svoju sposobnost za roditeljsku skrb i time automatski ostvaruje pravo na dijete.

\subsection{Diskriminacija istospolne zajednice dvaju muškaraca u odnosu} na istospolnu zajednicu dviju žena i neke zakonske mogućnosti

Uvriježeno je da u Hrvatskoj živimo u kulturi ljudskih prava i sloboda, te suzbijamo svaki oblik diskriminacije, svaku odluku ili zakon kojim se ograničavaju ljudska prava i slobode. Zakon o MPO čini upravo suprotno. On daje ženama pravo na umjetnu oplodnju, bez obzira na status. No onda se nameće pitanje: Diskriminira li Zakon o MPO mušku populaciju? Zakon ne spominje imaju li dvije žene koje žive u istospolnoj zajednici pravo na "prokreaciju« ili ga nemaju, dok se muškim partnerima to "pravo « izričito uskraćuje budući da eksplicitno navodi samo žene. To znači da lezbijski par ima pravo na prokreaciju, dok je muškom paru ta mogućnost uskraćena. Prema tome, može se govoriti da je ovaj zakon diskriminirajući jer stavlja muškarce u nepovoljan društveni položaj, odnosno neizravno su postali »građani drugoga reda«.

Ovo nas dovodi do konačnog zaključka, odnosno potrebe razmatranja nove moguće društvene problematike, a riječ je o zamjenskom majčinstvu kojim bi se mogao izbjeći bilo kakav oblik diskriminacije prema muškarcima koji teže za roditeljstvom, odnosno djetetom, a koji žele sebi osigurati pravo na prokreaciju na jednak ili sličan način kao i žene. Ovome, međutim, nadodajemo da bi želja za prokreacijom kod muških istospolnih parova mogla otvoriti novu vrstu društvenoga i moralnoga problema s tragičnim posljedicama na prava djece. Problem se odnosi na »trgovanje«, ali više nije riječ samo o jajnim stanicama već i o maternicama i utrobama žena koje bi bile spremne izaći ususret istospolnim muškim zajednicama, iako je bilo kakav oblik trgovanja izričito zabranjen u čl. 31. Zakona o MPO.

Izravnom zabranom bilo kakvoga oblika trgovanja djecom ili sklapanja poslova oko zamjenskog majčinstva, nije spriječena mogućnost suradnje dvaju 
istospolnih parova, ženskog i muškog. Vrlo je realno očekivati, barem zato da svatko ostvari svoju želju za potomstvom, novu društvenu i etičku problematiku u kojoj će dvije istospolne zajednice surađivati darivanjem onoga što je potrebno za začeće djeteta: sjeme i jajna stanica, te nošenjem i porodom djeteta. Vodeći se idejom zamjenskog majčinstva i njezina eventualnog ozakonjenja, ako je žena spremna slobodno i svjesno iznajmiti svoje tijelo, postoji zakonska mogućnost da neki ženski istospolni par surađuje s drugim muškim istospolnim parom te da svaka žena bude oplođena sjemenom jednog od muškaraca iz muške istospolne zajednice. Pri tome bi svaki od muškaraca i svaka žena iz tih zajednica/parova bio biološka majka ili biološki otac. S obzirom da bi u tome slučaju jedno dijete imalo biološkog oca u muškoj istospolnoj zajednici, a drugo dijete bi imalo majku u ženskoj istospolnoj zajednici - svaki od parova ima pravo na jedno dijete jer je, biološki gledano, to njegovo dijete.

Pitanje umjetne oplodnje u Zakonu o MPO nije samo problem neplodnih parova (kako se to ponajviše u početku isticalo), niti se zakonom samo njima željelo izaći ususret da bi nadišli ili pobijedili svoju patnju i bol, već je pitanje znatno šire i dublje. Ponajprije jer je zakon svojom nedorečenošću širom otvorio vrata raznim tumačenjima i manipulacijama. Društveni moral danas prvenstveno naglašava ulogu slobode, a ne samo prava. Osobna sloboda i narcističke želje su postale »zakon«, a pojedinac sam svoj »zakonodavac« koji određuje što mu je prihvatljivo, a što neprihvatljivo, što treba tolerirati, što diskriminirati itd. U duhu tih i takvih sloboda i prava, čak i istospolni parovi, kao i osobe koje ne žive ni u kakvoj zajednici (samci), mogu nekoga zvati sinom ili kćeri. ${ }^{18}$ Drugim riječima, sloboda pojedinca nadilazi slobodu drugoga, u ovom slučaju sloboda i prava istospolnog para koji teži za potomstvom, nadilaze prava djeteta da ima oca i majku i da bude začeto kao plod sjedinjenja u ljubavi oca i majke. Stoga se nameće sama po sebi tema dostojanstva i prava djeteta pri umjetnoj oplodnji u istospolnoj zajednici/paru.

\subsection{Diskriminacija djeteta u umjetnoj oplodnji u kontekstu istospolne zajednice}

U posvajanju i kod umjetne oplodnje valja se pozvati na čl. 3., st. 1. Zakona o MPO koji kaže sljedeće:

»U primjeni postupaka medicinski pomognute oplodnje štiti se dostojanstvo i privatnost osoba koje sudjeluju u postupku medicinski pomognute oplodnje, kao i osoba koje daruju spolne stanice, odnosno zametke.«

\footnotetext{
${ }^{18}$ Angelo SERRA, Madri e figli della provetta, u: PONTIFICIO CONSIGLIO PER LA FAMIGLIA, Famiglia e procreazione umana. Commenti sul documento, Città del Vaticano, Libreria editrice Vaticana, 2007, 199-216, 202.
} 
$\mathrm{Da}$, govori se o dostojanstvu, ali vrlo parcijalno jer se ističe samo, jedino i isključivo dostojanstvo osoba koje sudjeluju u medicinski pomognutoj oplodnji. Dakle, kako kod posvajanja tako i kod umjetne oplodnje, zanemaruje se dostojanstvo i pravo djeteta. A to je njegovo pravo na oca i majku jer oboje imaju vrijednu i nezamjenjivu ulogu u cjelovitom razvoju djeteta. Pravo na oca i majku, kao i pravo na cjeloviti odgoj i razvoj, jesu temeljna prava djeteta koje nalaže njegovo dostojanstvo upisano u njegovo srce. Cjeloviti razvoj u našem kontekstu osobito uključuje društvenu, moralnu i psihološku dimenziju, a koje su u našem slučaju kod istospolnih parova duboko ugrožene, pa čak i narušene i iskrivljene, barem na teorijskoj razini. Stječe se dojam da sloboda i prava istospolnih zajednica, ali i osoba koje ne žive niti u jednom obliku zajednice, nadilaze prava i dostojanstvo djeteta. Zakon i određivanje nekih prava kreirali su jači i moćniji i oni ne uvažavaju istinsku dobrobit djeteta već isključivo želje i prohtjeve roditelja, osobito u slučaju istospolnih parova. Dijete u svemu tome postaje metoda ostvarivanja tog povlaštenog položaja.

Pozivanje na pravo i slobode učinilo je tako dubok zaokret na području moralnih, antropoloških i psiholoških pitanja da ih se ne uzima relevantnim u rješavanju društvenih problema i pojava kojima se nastoji izmijeniti poredak stvaranja te zdravog života i suživota, a niti u razvoju djeteta. Prvi primjer o prokreaciji i ovaj drugi o dostojanstvu djeteta, postavljaju temeljno pitanje društvu:

Tko je i što je dijete koje treba biti začeto? Koja su njegova prava i koje je njegovo dostojanstvo? Gdje je ono u svemu tome kao subjekt, uza sve želje, zahtjeve i prava istospolnih partnera?

Nezanemariva je činjenica da dobro društva nisu samo bračni partneri i njihova prava već je, od trenutka začeća novoga života, dobro društva i dijete. Stoga društvo ima odgovornost i prema začetom djetetu, da mu se osigura sve što mu je potrebno za dostojanstven i kvalitetan život. Kod istospolnih parova dostojanstvo djeteta biva zanemareno, ponajprije radi načina njegova začeća $\mathrm{i}$ poziva na postojanje. Pri tomu se stječe dojam da je jedini razlog njegova začeća u tome da istospolni par samom sebi osigura status jednak onom heteroseksualnih brakova. A to uzrokuje teško srozavanje dostojanstva i temeljnih prava djeteta - da bude začeto radi sebe sama, iz ljubavi, a ne iz nekih drugih egoističnih pa čak i konzumerističkih motiva. S druge strane biva zanemareno djetetovo temeljno pravo na oca i majku, a čije su uloge u odgoju djece jednako potrebne. ${ }^{19}$ Slično je i u slučaju prava istospolnih parova na posvajanje djece. Posvajanje bi po svojoj naravi trebalo biti znak iskrene solidarnosti i ljubavi koja ne prestaje činom posvajanja ili osiguranja materijalne ili emotivne sigurnosti

\footnotetext{
${ }^{19}$ Usp. PAPINSKO VIJEĆE »IUSTITIA ET PAX«, Kompendij socijalnog nauka Crkve, Zagreb, Kršćanska sadašnjost, 2005, br. 242; Tony ANATRELLA, Una sfida della procreazione. Il bambino ha bisogno di un uomo e di una donna, u: Pontificio consiglio per la famiglia, Famiglia e procreazione..., 190-197.
} 
već se nastavlja odgovornim i cjelovitim odgojem djeteta, ne samo u psihološkom smislu već i u duhu moralnih i antropoloških istina o čovjeku i društvu.

Radikalan zaokret napravljen je upravo na antropološkom planu koji utvrđuje različnost spolova i njihovu komplementarnost, ${ }^{20}$ a ta se različitost u korijenu negira odgojem $u$ istospolnim zajednicama. Komplementarnost je jedino ostvariva u različitosti spolova, a započinje tjelesnim sjedinjenjem muškarca i žene i dalje se nastavlja duhovnim, psihološkim i moralnim razvojem djeteta. Takvom cjelovitošću odgoja djeteta bračna zajednica na kvalitetan način ostvaruje i svoje obveze prema društvu jer je svaka individua dobro društva u kojoj ono ima svoj opstanak i zdravu budućnost. Uzimajući u obzir moguć moralni i društveni nered, koji se ne odnosi samo na prokreaciju već i na odgoj djeteta, ljudsko društvo stoji pred zahtjevom vlastita dostojanstva i odgovornosti da radi za dobro pojedinca, ali i za opće dobro.

Prema tome, cjelokupno društvo je dužno preispitati narav ovih veza i prava koja oni omogućuju, a koji duboko vrijeđaju dostojanstvo involviranih subjekata, a ponajviše djeteta. Naime, nekim članovima ljudskoga društva prijeti opasnost da kao osoba/donor sjemena ili jajnih stanica ne bude tretiran i poštivan kao osoba/subjekt već kao nositelj materijala potrebnog za prokreaciju. Nastaje teška povreda antropoloških i moralnih istina koje se očituju u razdvajanju onoga što čovjek-pojedinac jest i one moći kojom ga je Bog obogatio i osposobio za razmnožavanje (sjeme ili jajna stanica) u tjelesno-duhovnom sjedinjenju i ostvarivanju vlastite obitelji i istinske suradnje s Bogom Stvoriteljem.

Prvi zadatak društva jest razumijevanje i tumačenje ljudskih prava u svjetlu istine o čovjeku i njegovoj naravi, tj. da posljednji izvor ljudskim pravima nije u ljudskim željama, idejama, ni u pukoj volji krvi i mesa, niti države, već da se nalazi u čovjeku i Bogu, njegovu Stvoritelju. ${ }^{21}$ Riječ je ponajprije o dostojanstvu čovjeka kao slike i prilike Božje i o naravnom zakonu koji je univerzalan i nepovrediv. Kompendij socijalnog nauka Crkve s tim u vezi se poziva na govor Ivana Pavla II. Sudu Rimske rote:

»U svjetlu takve antropologije otkriva se koliko je neumjestan zahtjev da se bračno stanje pripiše vezi između osoba istoga spola. Tome se nadasve suprotstavlja objektivna nemogućnost da ta veza donese plod preko prenošenja života, prema naumu što ga je Bog upisao u samo ustrojstvo ljudskoga bića. Osim toga, zapreka je nedostatak pretpostavki za tu međuosobnu komplementarnost između muškarca i žene koju je Stvoritelj htio, kako na fizičko-biološkom planu tako i na onome koji je istaknuto psihološki. Samu u jedinstvu između dvije osobe različite po spolu može se ostvariti usavršavanje pojedinca, u sintezi jedinstva i uzajamnoga psiho-fizičkoga upotpunjenja.« ${ }^{22}$

\footnotetext{
${ }^{20}$ Usp. Papinsko vijeće »Iustitia et pax , Kompendij socijalnog nauka Crkve..., br. 224.

${ }^{21}$ Usp. isto, br. 153.

${ }^{22}$ Isto, br. 228.
} 
Antropološki, etički, moralno i društveno je neprihvatliivo opetovano pozivanje na toleranciju u državnom ozakonjivanju istospolnih zajednica i dodjeljivanju prava koja su do sada pripadala samo i jedino heteroseksualnim brakovima. To je odraz nezrelosti i neodgovornosti za opće dobro te gaženje naravnih i moralnih zakona na kojima počiva ljudsko društvo, a kojima ono zahvaljuje svoju povijest i sadašnjost.

\section{Zaključak}

Pokazali smo u ovom članku koliko je u 21. stoljeću intenzivirana suradnja između zakonodavne vlasti i LGBTIQ udruga. Pozivajući se na ljudska prava i slobode učinjen je dubok zaokret na području društvenih i pravnih pitanja jer se relevantne znanstvene discipline - kao što su filozofija, etika, antropologija, biologija, psihologija i medicina - gotovo nimalo ne uvažavaju kao bitne u rješavanju društvenih problema i pojava. Stječe se dojam da zakonodavna vlast ima isključivo zadatak jamčiti i osigurati svakom građaninu da slobodno i nesmetano ostvaruje svoja prava, posebice ako je riječ o manjinskom i »ugroženom « sloju društva, kakvim se nerijetko prikazuju osobe homoseksualne orijentacije. U tom slučaju njihovo pozivanje na diskriminaciju jest snažan obrambeni aparat kojim se guše znanost i znanstvene činjenice, a time i interdisciplinarni dijalog zakonodavne vlasti i drugih relevantnih znanstvenih disciplina.

Iz članka je, nadalje, vidljivo da nitko ne može i ne smije uskraćivati pravo na dostojanstven život osobama homoseksualne orijentacije, što bi trebao biti naravni predmet zakona, no etički je nedopustivo da zakon svjesno i namjerno zanemaruje medicinu, jedinu legitimnu za utvrđivanje neplodnosti kao patologije - i to ne samo poradi "prava" na umjetnu oplodnju već i s obzirom na dostojanstvo djeteta, za kojim toliko teže istospolni parovi.

Budući da zakon mora voditi računa o svim građanima, o njihovim pravima i dostojanstvu, onda je nedopušteno zanemariti položaj djeteta pri reguliranju umjetne oplodnje kod istospolnih parova, neovisno o tome što ono još nije začeto. Dijete nikada ne smije tretirati kao objekt već kao subjekt i time nositelj prava na oba roditelja i prava da bude začeto prirodnim putem, odnosno u ljubavno-tjelesnom sjedinjenju svojih roditelja. Ovdje se, stoga, nameću mnoga sasvim legitimna pitanja oko moralno-pravno-društvenog statusa djeteta. Smatramo da se zakonodavna vlast suočava s nuždom konstruktivnog dijaloga kada je u pitanju zaštita svakog građanina, kako onog već živućeg tako i onog koji je tek u planu.

Prvi bi, stoga, zadatak zakonodavne vlasti bio poštivanje i uvažavanje interdisciplinarnog pristupa medicine i etike i ostalih relevantnih znanstvenih disciplina, radi toga da se i osobama koje traže svoja prava i osobama koje su objekti tih istih prava, osigura temeljna zaštita dostojanstva, a na samom kraju 
i pravo na život i pravo na zdrav obiteljski okoliš. Zakon ima dužnost štititi prava svojih građana, ali isto tako i štititi vječni zakon koji uključuje naravni moralni zakon koji je univerzalan, nepromjenjiv i nepovrediv. Ljudski zakon, naime, nema ovlasti zanemarivati znanstvene discipline jer su one također $u$ službi čovjeka. Niti smije biti protiv onoga što u konačnici čini njegov prvobitan etički zahtjev: čuvati i štititi život i zdravlje. Međutim, u ovom se slučaju ljudski zakon postavio apsolutnim i nepovredivim etičkim kriterijem, a sve je znanstvene discipline stavio u podređeni položaj.

Dakako, nismo za progon niti za umanjivanje prava osoba homoseksualne orijentacije i istospolnih parova, već upozoravamo da zakon nije u skladu sa znanstvenim disciplinama koje mogu doprinijeti rješavanju problemâ koje taj isti zakon pokušava regulirati. 


\section{Mislav Kutleša ${ }^{*}$ - Mladen Škvorc ${ }^{* * *}$ \\ Ethical challenges in reproductive medicine and the Law of medically assisted insemination in the context of same-sex unions}

\section{Summary}

Whole 20th century was designated by sudden and rapid development of science, trough whom we especially mark medicine, biomedicine and bioengineering, which left nobody indifferent, as we can see in challenges and debates created by relationship between science and ethics. Although named sciences were rapidly evolved achieving amazing success in the field of human health and life, simultaneously with them was developed awareness of the need to respect ethical principles. Ethical principles were primarily related to the position, value and dignity of human in the horizons of scientific research and reach. In modern age, it refers to the relationship that is created by reproductive medicine, respectively medically assisted conception, against infertility and position of the child. Although, conditionally saying, initially artificial insemination had sense within the marriage and cohabitated infertile couples, recently appeared special ethical issues in the context of same-sex unions that de facto have equal rights same as cohabitation between a man and a woman. At this point, we especially extricate the right to offspring achievable by medically assisted insemination.

Key words: medically assisted insemination, infertility, Law of medically assisted insemination, right to child, same-sex partnerships, responsible procreation.

(na engl. prev. Mladen Škvorc)

\footnotetext{
* Mislav Kutleša, PhD, senior assistant on Faculty of Theology, University of Zagreb; Address: Vlaška 38, pp 432, HR-10001 Zagreb, Croatia; E-mail: mkmoraltheol32@hotmail.com.

*** Mladen Škvorc, MA, Master of Science, vice-chancellor of Archdioceses of Zagreb; Address: Kaptol 31, pp 553, HR-10001 Zagreb, Croatia; E-mail: mlaskvor@gmail.com.
} 